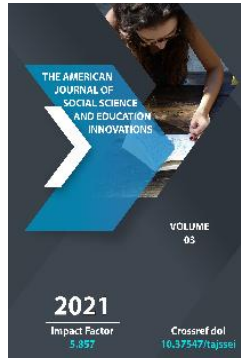

\title{
Learning Business Game As An Effective Form Of Organization Of The Process Of Advancing The Process Of Leaders Of Preschool Educational Organizations
}

\author{
Qosimova Shakhnoza Nuriddinovna \\ Independent Researcher, Institute For Retraining And Advanced Training Of Directors And \\ Specialists Of Preschool Education, Tashkent, Uzbekistan
}

Journal Website:

http://usajournalshub.c

om/index,php/tajssei

Copyright: Original content from this work may be used under the terms of the creative commons attributes 4.0 licence.

\section{ABSTRACT}

The article highlights the role of educational games as an effective form of organization in the process of professional development of leaders of preschool education, its content and essence.

\section{KEYWORDS}

Competence, leadership training, competence, preschool organization, educational game, effective form, professional qualities.

\section{INTRODUCTION}

In the modern socio-economic situation, the development of professional competence of management personnel should be considered as a backbone component of their professional activity, management ensuring the continuity of improving the skills of performing functions, developing the personal professional qualities of the head of a preschool education institution.

The tasks that arise today for preschool educational institutions require the formation of new competencies in their leaders, a readiness to solve non-standard situations, the 
careful preservation of positive traditions and the inclusion of innovations in the process of raising their professional level.

The essence of advanced training is globally defined in the advanced training of management personnel, the meaning of which is not so much in saturating students with a certain amount of information, but in developing such skills as the ability to operate with information, design and model their activities.

\section{MATERIALS AND METHODS}

The formation of professional competence is achieved when the prescription-information approach is replaced by a competency-based approach, making the student an active participant in the search for solutions to typical problems arising in his activities. The new values of education that arise in the process of its modernization are the foundations of the competence-based approach, the essence of which is that education should, having overcome the elements of abstract content, become a factor in solving life problems for each specific person. The competence-based approach in this case assumes the individualization of education, its unconditional human orientation, developmental orientation and age adequacy [1].

From this position, it is important to determine the forms of organization of the educational process in the system of additional education for adults. One of the most effective forms, in our opinion, is the educational business game.

An educational business game is a form of recreation of the subject and social content of a specialist's professional activity, modeling of such systems of relations that are characteristic of this activity as a whole [4; 5].

Since in a business game the "subject of activity" performs a quasi-professional (according to A.A. Verbitsky) activity that combines educational and professional elements, therefore, knowledge and skills are acquired by him not abstractly, but in the context of the profession.

At the same time, the student, along with professional knowledge, acquires or improves other professionally significant "competencies": communication skills, collegiality, the ability to lead and obey, psychological stability, etc.

\section{RESULT AND DISCUSSION}

The implementation of the educational goals outlined by the teacher, already at the stage of designing a business game, requires taking into account several psychological and pedagogical principles: the principle of simulation of the situation, the principle of problematic content, the principle of role interaction in joint activities, the principle of dialogical communication, the principle of twodimensionality of game educational activity [3; $4 ; 5]$.

The use of educational business games in the process of raising the qualifications of managers of preschool institutions makes it possible to ensure a number of the most important provisions of adult education:

- An adult who is learning has a leading role in the learning process. The function of the teacher in this case is to assist the student in identifying, systematizing, formalizing 
his personal experience, adjusting and replenishing his knowledge;

- Being a mature person, an adult sets specific learning goals for himself, strives for independence, self-realization, selfgovernment;

- An adult has professional and life experience, knowledge, abilities, skills that can and should be used in the process of teaching himself and his colleagues;

- An adult is looking for the earliest possible application of the knowledge and skills gained during training, etc. [2].

Participation in an educational business game allows managers not only to better understand the essence of the phenomena, but also to improve the skills of making managerial decisions. The game model well imitates real processes or individual aspects of the development of a socio-pedagogical system, allows you to feel the connections, understand the mechanism of their action, and thus learn how to manage and influence them. Educational business games are conducted by the teachers of the department to improve the qualifications of management personnel on topical issues and areas of their professional activity.

To improve the professional competence of various categories of specialists in the preschool education system, the teachers of the department have developed educational business games concerning the content of the work of the heads of preschool institutions, their deputies for the main activity. Each game consists of several stages.
The organizational stage allows the listeners to get to know each other better, establish contact, tune in to interaction and creative search, and the teachers to update the listeners' knowledge on the topic of the game. In the structure of the stage, most games have a small lecture block (mini-lecture-discussion), when the teachers provide the most essential information on the topic, and then problem situations are created for the working groups. Creative work assumes that the participants have certain knowledge on the topic, supplemented and systematized by the teachers. When completing the task together in microgroups, the knowledge and skills of the listeners expand, i.e. there is a mutual learning in practical activities. At the end of the game, a reflective stage is necessarily held, allowing the listeners to analyze the novelty of the material under consideration and its relevance, their own activity during the game, etc.

The educational business game is not only the most important tool for educational communications, but also helps the leader to understand his own management experience.

The use of methods of organizing joint discussions within the framework of the game can significantly reduce the time for generating ideas, contributes to the mastery of a large amount of information and the exchange of management experience.

In the process of group work and intergroup discussions, the problems of the future development of preschool institutions are raised, ways of their solution are outlined and discussed, and possible difficulties of their implementation are imitated. 
Participation, for example, in such an educational business game as "Management activity as a mechanism for improving the quality of preschool education" is noted by the listeners of great interest and effectiveness. Its tasks are to increase the level of managerial competencies of heads of preschool education institutions, improve the skills of setting goals, analysis, forecasting, strategic planning, and motivating the team to ensure the quality of education. Let's briefly dwell on some of the components of this game.

During the preparatory stage, the students' knowledge in the field of the main functions of management activities is updated and the attitude of the participants towards them is identified. This stage is based on facilitation ("What functions do a manager need to perform for effective work?") And a modified form of the "Four Corners" method.

During the main stage, goal-setting skills are practiced using the SMART method. Further, in microgroups, an algorithm for strategic planning of the activities of a preschool institution is developed (based on an analysis of the content of analytical reports) and a presentation of the developed strategic plan schemes is carried out. Improving management skills for the implementation of the functions of the organization and leadership of the team of a preschool institution is based on the method of situational analysis (case-study). For group work, tasks are offered related to delegation of authority, conflict resolution, identification of typical mistakes in exercising control, methods of motivating subordinates and selfmotivation.
The use of SWOT analysis helps to identify the strengths and weaknesses of preschool education institutions, and, consequently, opportunities and threats, when organizing, for example, innovative activities, educational services on a paid basis.

In conclusion, the participants of the game conduct a reflexive assessment of the activity, summarize the results of the educational business game.

Educational business games contribute to the formation of a creative approach to management activities, help to increase its efficiency, make it better, make them rethink the emerging problems and reassess their own capabilities, ultimately stimulate the leaders of preschool education institutions to strive for professional self-development.

The inclusion of educational business games in the process of improving the qualifications of leaders of the preschool education system allows you to activate students, use their knowledge and practical experience, assess the degree of assimilation of educational material, accelerate the process of liberation from stereotypes of professional behavior and authoritarian management, develop business skills necessary in modern conditions: independence in decision-making and goal setting, the ability to defend one's point of view, focus on success and cooperation by expanding the communication space.

Educational business games help the heads of preschool institutions to carry out direct and feedback, receive the necessary information, use their influence to implement management strategies, take a fresh look at the problems, actualize the reflexive position of management 
personnel associated with the awareness of themselves as a subject of their own activities. They act as a kind of link between theory and practice and represent a "volumetric projection" of didactics on the practical activities of the heads of preschool institutions, allow students to be maximally involved in analytical work connecting theory and practice, provide dialogization in the interaction of teachers and students, problematization as a means of activating and becoming the subjectivity of the student in the educational process, personalization - the inclusion of real personal experience, and, finally, individualization - focus on the dynamics of the individual development of listeners.

\section{CONCLUSION}

Thus, the use of educational business helps to increase the professional competence of management personnel of preschool institutions in general and of each of its structural components, in particular, ensures the orientation of managers to the formation and self-development of professional competence, subject position in relation to their own professional activities.

\section{REFERENCES}

1. Active forms of work in the process of professional development

2. Competence approach in pedagogical education [Text] / V.A. Kozyrev [and others]. - SPb. : Publishing house of the RGPU im. A.I. Herzen, 2004 --- 392 p.

3. Education of adults: experience and problems / ed. S.G. Vershlovsky. - SPb. : IOV RAO, 2002 .-- 165p.
4. Oleshkov, M. Yu. Business game in the system of professional training of students // Scientific notes of NTGPI. Pedagogy and psychology. - Nizhny Tagil, 2002 .-- P. 57-63.

5. Trainev, VA Business game in the educational process / VA Trainev. - M.: Prometheus, 2002 .-- $345 \mathrm{p}$. 